Nig. J. Biotech. Vol. 38 (2) : 84-91 (Dec 2021)

ISSN: 01891731

Available online at

http://www.ajol.info/index.php/njb/index

and www.biotechsocietynigeria.org

DOI: https://dx.doi.org/10.4314/njb.v38i2.9

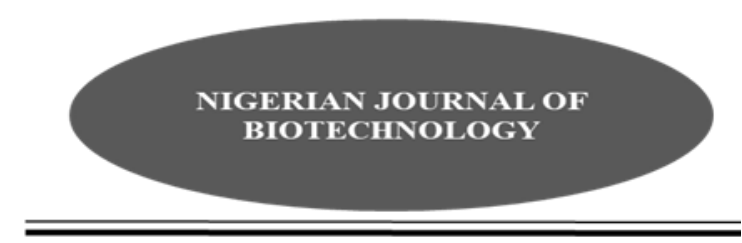

\title{
Characterization of Some Novel Antimicrobial Peptides from African Common Toad, Sclerophrys regularis
}

\author{
Aliyu, A. ${ }^{1 *}$, Ibrahim, Y.K.E. ${ }^{2}$ and Tytler, B.A. ${ }^{2}$ \\ ${ }^{1}$ Department of Pharmaceutical Microbiology \& Biotechnology, University of Ilorin, Ilorin Nigeria \\ ${ }^{2}$ Department of Pharmaceutical Microbiology, Ahmadu Bello University, Zaria Nigeria
}

\begin{abstract}
The growing number of antimicrobial resistant bacteria have necessitated urgent need for newer and effective antimicrobials. Antimicrobial peptides (AMPs) which are also called host defense peptides are promising class of bioactives found in all living thing especially amphibians. A total of 355 Sclerophrys regularis were collected and each toad was weighed and $0.02 \mathrm{~mL} / \mathrm{g}$ of epinephrine $(1 \mathrm{mg} / \mathrm{mL})$ was administered via the dorsal lymph sac of the toad. The skin secretions were washed, lyophilized and stored at $-20^{\circ} \mathrm{C}$. The secretion was purified using Sephadex G-50 gel purification column. The fractions showing antimicrobial activities against Pseudomonas aeruginosa ATCC 27853, Escherichia coli ATCC 25922, Salmonella typhii ATCC 14028, Citrobacter freundii ATCC 8090, Staphylococcus aureus ATCC 25913 and Candida albicans ATCC 3147 were further purified by RP- HPFC. The purified fractions were lyophilized and $\mathrm{m} / \mathrm{z}$ ratio peaks were determined using MALDI TOF/TOF MS. The sequences corresponding to the peaks were determined using Mascot Peptide Mass Fingerprint which revealed novel AMP sequences: IHAGKTVPIVK, MHLLWR and LTGQIKNGLSGR which were named Regularin-2, Regularin-3 and Regularin-4 respectively. The MICs of purified fractions were between $50-200 \mu \mathrm{g} / \mathrm{mL}$ and the antimicrobial activities were maintained when stored at $-20{ }^{\circ} \mathrm{C}$ for 180 days and was significant at $p<0.05$. Bioprospecting of Nigerian toad specie ( $S$. regularis) could yield potential therapeutic AMP agents.
\end{abstract}

Keywords: African common toad, Antimicrobial peptides, AMPs, Sclerophrys regularis, Toad skin secretion.

*Corresponding author Email: aliyu.a@uniloin.edu.ng, Tel: +234 - 8037553870

\section{Introduction}

The discovery of antibiotics was a major breakthrough in medicine (Govender et. al., 2012). However, the sudden uprising of multidrug resistant bacteria now establishes an imminent danger to the effective treatment of infectious diseases leading to high morbidity, mortality and prolonged stay in hospital. One of the major global public health problems is the resistance to existing antibiotics (Katerrere et. al., 2013). This resistance to antibiotics has increased and spread to many organisms both in the neighbourhoods and healthcare facilities, where the latter is responsible for the majority of deaths. In the U.S, it is reported that greater than 2.8 million people are usually infected with antibiotic-resistant organisms each year, and that over 35,000 people died because of these antibiotic-resistant infections (CDC, 2020). Consequently, continuous searching for effective antimicrobials has become a necessity (Colon \& Sonnevend, 2011; Govender et. al., 2012).

Amphibians are animals that live in a habitat that support proliferation of microorganisms, but majority of them possess adaptive features that prevent colonization of their skin by these pathogenic organisms. These features include their skin secretion which contains Antimicrobial Peptides "AMPs" (Mor \& Nicolas, 1994). These AMPs constitutes their innate immune system. 
Aliyu et al. / Nig. J. Biotech. Vol. 38 Num. 2 : 84-91 (December 2021)

One of the mechanisms by which toads and frogs protect themselves against predators and pathogens is through secretions from their granular glands on the skin. These secretions are different from one specie to the other and could be marginally noxious to greatly lethal (Siano et. al., 2014; Liberio et. al., 2014). These glandular secretions particularly the Antimicrobial Peptides (AMP) are promising agents to combat a wide spectrum of bacteria (Dailami et. al., 2016).

Moussa et. al. (2015) reported that peptide secretions from a frog (Rana ridibunda) exerted bactericidal action against Gram-positive organism such as methicillin-resistant Staphylococcus aureus, Gram-negative bacteria including ESBL producing Klebsiella pneumoniae, and Escherichia coli and yeast (Candida albicans). A South American frog, Pithecopus hypochondrialis has been reported by Chengbang et. al. (2017) to secretes an AMP, Dermaseptin$\mathrm{PH}$, which possess antimicrobial activities against pathogenic yeast, Gram-positive and Gramnegative bacteria.

Globally, peptides from only a few species of toad have been studied and further screening of other species is expected to yield new antimicrobial peptides (Govender et. al., 2012). These antimicrobial peptides would provide alternatives to tackle the multi-drug antibiotic resistance (Katerrere et. al., 2013). Published reports on the biological activities of African, especially Nigerian, toads' secretions are limited. This study is therefore aimed at studying the secretions from Nigerian toad in attempt to search for new antimicrobial agent of broad spectrum with little or no resistance.

\section{Materials and methods}

\section{Collection of sample toads and secretions}

African common toad (S. regularis) were collected using a net and basket trap at night from Ilorin (Lat. $8^{\circ} 28^{\prime} 46^{\prime \prime} \mathrm{N}$ and Long. $4^{\circ} 40^{\prime} 44^{\prime \prime} \mathrm{E}$ ), Lafiagi (Lat. $8^{\circ} 45^{\prime} 08^{\prime \prime} \mathrm{N}$ and Long. $5^{\circ} 14^{\prime} 16^{\prime \prime} \mathrm{E}$ ) and Shonga (Lat. $9^{\circ} 00^{\prime} 59^{\prime \prime} \mathrm{N}$ and Long. $5^{\circ} 18^{\prime} 04^{\prime \prime} \mathrm{E}$ ). The toads were identified using criterial set out in AmphibiaWeb (https://amphibiaweb.org/c gi/amphib query?wheregenus=Sclerophrys\&whe re-species=regularis ) and authenticated at zoology department, university of Ilorin. After nine trips to the sites of collection a total of 355 toads were sampled. Each toad was weighed and administered epinephrine $(1 \mathrm{mg} / \mathrm{mL}) 0.02 \mathrm{~mL} / \mathrm{g}$ of toad body weight via the dorsal lymph sac to stimulate skin secretion. The skin secretion was then washed using $0.1 \mathrm{M} \mathrm{NaCl}$ solution containing $0.01 \mathrm{M}$ EDTA. The washings of the toads were pooled and centrifuged at $13000 \mathrm{rpm}$ and the supernatant was lyophilized and stored at $-20^{\circ} \mathrm{C}$ as described by Moussa et. al. (2015).

\section{Partial purification}

The method of Moussa et. al. (2015) was adopted. To $400 \mathrm{~mL}$ of $0.1 \mathrm{M}$ phosphate buffer $(\mathrm{pH} 6)$, ten (10) grams of Sephadex G-50 (Amersham Biosciences, Sweden) was added, mixed and left to swell for 1 hour. Thereafter, the mixture was filtered. The gel was acidified with $1.0 \mathrm{~L}$ of $0.2 \mathrm{M}$ $\mathrm{HCl}$ which was followed by the elution of the phosphate buffer. The gel was kept at $4^{\circ} \mathrm{C}$ for 4 days to allow complete swelling and the surplus eluent was decanted.

Chromatographic column $(20 \mathrm{~cm} \times 2.7 \mathrm{~cm})$ plugged with sterile cotton wool was used to pack and equilibrate the gel by pouring thick slurry of the gel into it. The gel was allowed to settle and equilibration with $2.5 \mathrm{M}$ phosphate buffer $(\mathrm{pH} \mathrm{6})$ continued until flow rate of $2 \mathrm{~mL} / 5$ min was achieved and a layer of the buffer was maintained above the packed gel surface.

The $9.0 \mathrm{~g}$ of lyophilized powder was suspended in $40 \mathrm{~mL}$ of solution of $5 \mathrm{mM}$ EDTA in $0.1 \mathrm{M}$ phosphate buffer ( $\mathrm{pH}$ 6.0). The layer of the buffer above the gel surface was drained, and the lyophilized powder suspension was carefully placed onto the top of the gel bed. The solution was then eluted with $0.5 \mathrm{M}$ potassium phosphate buffer at a flow rate of $2 \mathrm{~mL} / 5 \mathrm{~min}$ and the fractions monitored at $280 \mathrm{~nm}$. All this was repeated with another $9.0 \mathrm{~g}$ of lyophilized powder using freshly packed column. The partially purified eluates were pooled into four fractions, lyophilized and stored at $-20^{\circ} \mathrm{C}$.

\section{Purification using flash chromatography}

Reverse phase high performance flash chromatography, RP-HPFC, (Biotage Isolera ${ }^{\mathrm{TM}}$ ) flash purification system equipped with Biotage ${ }^{\circledR}$ SNAP Bio $C_{18} 300 \AA 25 \mathrm{~g}$ cartridge was used to further purified the lyophilized fractions. A $500 \mathrm{mg}$ of partially purified peptide was dissolved in $15 \mathrm{~mL}$ of $50 \%$ aq. acetonitrile. A $5 \mathrm{~mL}$ sample was injected on to a Biotage ${ }^{\circledR}$ SNAP Bio $\mathrm{C}_{18}$ flash cartridge. Elution was performed using Solution $A$ (Milli-Q water) was used to elute the peptide with 5 to $90 \%$ concentration gradient with solution B (Acetonitrile) for $65 \mathrm{~min}$. At wavelength of 280 $\mathrm{nm}$, the abundance of the peptide fraction was monitored and the pure peptide fractions pooled. 
Aliyu et al. / Nig. J. Biotech. Vol. 38 Num. 2 : 84-91 (December 2021)

The purity of the fractions was evaluated using RP-HPLC.

\section{Antimicrobial Susceptibility Testing of purified fractions}

The purified fractions were assayed for antimicrobial activity against these standard cultures: Pseudomonas aeruginosa ATCC 27853, Escherichia coli ATCC 25922, Salmonella typhii ATCC 14028, Citrobacter freundii ATCC 8090 Staphylococcus aureus ATCC 25913, and Candida albicans ATCC 3147.

The method of Artika et. al. (2015) was slightly modified and used for antimicrobial activity determination. Mueller Hinton agar (Oxoid) medium was prepared as described by the manufacturer, it was then poured into sterile 90 $\mathrm{mL}$ petri dish and allowed to solidified. A $50 \mu \mathrm{L}$ of 0.5 McFarland turbidity bacteria culture was used to flood the agar surface and the excess then decanted carefully. Wells of $5 \mathrm{~mm}$ diameter were bored in the agar and $100 \mu \mathrm{L}$ of the purified fractions of toad skin secretion $(400 \mu \mathrm{g} / \mathrm{mL})$ was applied.

The three (3) purified lyophilized fractions were assayed for antimicrobial activity against the standard cultures and described above. Ciprofloxacin and ketoconazole were used for bacteria and fungus positive control respectively, while for the negative control $100 \mu \mathrm{L}$ of phosphate buffer solution $(0.5 \mathrm{M})$ was used. This was carried out in triplicate and incubated at $37^{\circ} \mathrm{C}$ for 24 hours. The diameters of zones of inhibition were recorded to determine the extent of each bacterium that was inhibited.

\section{Determination of MIC}

In carrying out the minimum inhibitory concentration (MIC), modified method of James et. al. (2010) was used. Mueller Hinton broth (Oxoid) was used to prepare $0.8 \mathrm{mg} / \mathrm{mL}$ peptide stock concentration. To a 96-well microplate, 100 $\mu \mathrm{L}$ sterile Mueller Hinton broth were distributed to the wells of the microplate. To column 1 of the plate $100 \mu \mathrm{L}$ of the prepared peptide stock solution was added, from this, serial dilutions of $8.0 \times 10^{-1}-7.8 \times 10^{-4} \mathrm{mg} / \mathrm{mL}$ of peptide were prepared up till column 10 . From the column 10 , $100 \mu \mathrm{L}$ was discarded.

A $5.0 \mu \mathrm{L}$ of prepared bacteria suspension was dispensed in columns 1 to 11 of the microplate. Column 12 was without bacteria, for broth sterility check and also used as blank for reading plates in the scanner. For each organism, this was done in triplicate and thereafter, the microplates were incubated at $37^{\circ} \mathrm{C}$ for 24 hours. An ELISA reader was used at $680 \mathrm{~nm}$ wavelength to electronically read the absorbance of the turbidity of the microplates content.

\section{Determination of physicochemical properties}

Methods described by Adriano et. al. (2013) were used to determine the susceptibility of the peptides to the effect of Proteinase- $K$ (a proteolytic enzyme), and effect of temperature and time on the antibacterial activity of the peptides. For the susceptibility to proteolytic enzyme, the most active fraction (Regularin-3) was incubated at $37^{\circ} \mathrm{C}$ in two concentrations (5.0 and $10.0 \mathrm{mg} \mathrm{mL}^{-1}$ ) of Proteinase $\mathrm{K}$ for $60 \mathrm{~min}$. The residuary antibacterial action against Pseudomonas aeruginosa ATCC27853 was determined. Effect of heat on antibacterial activity of Regularin-3 was ascertained after it was exposed to temperatures of 50 and $90{ }^{\circ} \mathrm{C}$ for 30 minutes, and antibacterial activity was reevaluated. Effect of time on stability was studied by the determination of residual antibacterial activity after the storage times of 90 and 180 days of the Regularin-3 samples kept at $-20{ }^{\circ} \mathrm{C}$ temperature.

\section{Peptides Sequencing}

Peptide sequencing was carried out using MS, in positive ionization mode on a MALDI-TOF/TOF instrument [Ultraflex, (Bruker Daltonics, Inc., Billerica, MA, USA)]. The freeze dried regularins were reconstituted using $10 \mathrm{~mL}$ of $0.1 \%$ TFA ( $\mathrm{v}$ : v). A $1.0 \mathrm{~mL}$ solution of each regularin solution was applied to MALDI target plate, and the same volume of recently prepared $5 \mathrm{mg} / \mathrm{mL}$ solution of 4-hydroxy-a-cyano-cinnamic acid (Sigma-Aldrich, St. Louis, MO, USA) in $50 \%$ aqueous acetonitrile containing $0.1 \%$ trifluoroacetic acid (TFA) as described by Asoodeh et. al. (2012). The $\mathrm{m} / \mathrm{z}$ spe ctral from MALDI was interpreted using peptide mass fingerprint (PMF) of Mascot webserver (https://www.matrixscience.com/cgi/search form .pl?FORMVER=2\&SEARCH=PMF) (Yergey et. al., 2015; Genomics Lab, 2012, Creative proteomics, 2017; Chen et. al., 2020)

\section{Results and discussion}

\section{Collection of sample and skin secretion}

Ponds at different sample collection towns served as the site of collection of toads. A total of 355 Sclerophrys regularis toads were collected from the study sites (Fig. 1). The average weight of the 
Aliyu et al. / Nig. J. Biotech. Vol. 38 Num. 2 : 84-91 (December 2021)

toads was $63.72 \mathrm{~g}$ and the average yield of

lyophilized skin secretion was $108.5 \mathrm{mg} /$ toad.

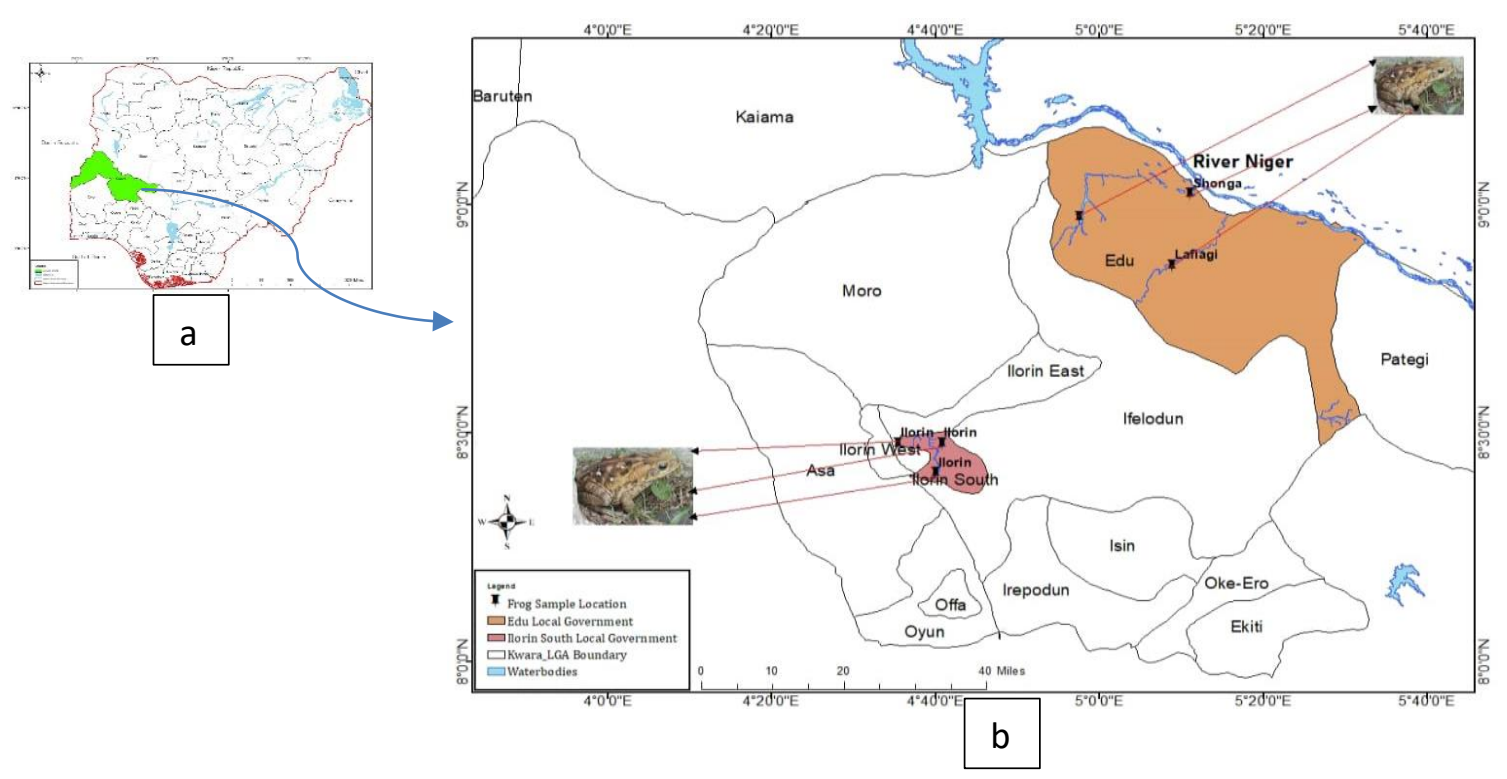

Figure 1: Map of Nigeria showing Kwara state (a) and towns (b) where toads were collected

Purification and AST of skin secretions

The purified fractions of SR2, SR3, and SR4 upon lyophilisation yielded $0.684 \mathrm{~g}, 1.813 \mathrm{~g}$ and 1.973 $\mathrm{g}$ respectively. The fractions were found to inhibit the growth of both Gram negative and Gram positive organisms and yeast. SR-3 exhibited highest antimicrobial activity followed by SR-2 and SR-4 was the least active fraction against the test organisms (Table 1.0).

Table 1: Antimicrobial susceptibility test of purified AMPs from S. regularis using agar well diffusion method

\begin{tabular}{|c|c|c|c|c|c|}
\hline \multirow{2}{*}{ Test Organisms } & \multicolumn{5}{|c|}{ Diameters of Zones of Inhibition (mm) } \\
\hline & SR-2 & SR-3 & SR-4 & CIP & KCZ \\
\hline \multicolumn{6}{|l|}{ Pseudomonas } \\
\hline aeruginosa & & & & & \\
\hline 27853 & $27.00 \pm 0.52$ & $28.50 \pm 1.14$ & $11.00 \pm 0.24$ & $22.00 \pm 0.74$ & - \\
\hline Escherichia coli ATCC & & & & & \\
\hline 25922 & $21.50 \pm 0.74$ & $23.00 \pm 0.34$ & $12.00 \pm 1.14$ & $21.50 \pm 0.51$ & - \\
\hline Salmonella typhii ATCC & & & & & \\
\hline 14028 & $24.50 \pm 0.31$ & $29.00 \pm 0.84$ & $12.50 \pm 0.14$ & $25.00 \pm 0.89$ & - \\
\hline Staphylococcus aureus & & & & & \\
\hline ATCC 25913 & $20.00 \pm 0.15$ & $22.50 \pm 0.77$ & $11.50 \pm 1.24$ & $22.00 \pm 0.13$ & - \\
\hline Citrobacter & & & & & \\
\hline ATCC 8090 & $21.00 \pm 0.22$ & $21.00 \pm 0.39$ & $13.00 \pm 0.18$ & $23.00 \pm 0.61$ & - \\
\hline
\end{tabular}


Aliyu et al. / Nig. J. Biotech. Vol. 38 Num. 2 : 84-91 (December 2021)

Candida albicans ATCC

3147

$19.50 \pm 0.63 \quad 21.50 \pm 0.61 \quad 12.00 \pm 0.63$

$18.50 \pm 1.42$

CIP = Ciprofloxacin,

$\mathrm{KCN}=$ Ketoconazole

Specifically, SR-3 gave highest zone of inhibition against Salmonella typhii ATCC14028 followed by Pseudomonas aeruginosa ATCC27853. Except with Citrobacter freundii ATCC8090, SR-3 exhibited better activities against the organisms than the reference ciprofloxacin. Wu et. al. (2021) isolated low molecular weight AMPs from Chinese frog skin secretion named chensirin-1 and chensirin-2 after purifying with both Sephadex G50 and RP HPLC, and a novel amphibian AMP as also been reported to demonstrate potent antimicrobial activity against planktonic ESKAPE microorganisms and Candida albicans (Liu et. al., 2020) which are similar to some organisms used in this study.

Physicochemical properties of the most active fraction

The AMP (SR-3) showed heat tolerance at $50^{\circ} \mathrm{C}$, but at higher temperature of $90^{\circ} \mathrm{C}$ there was total loss of antibacterial activity when it was exposed for 30 minutes. The antibacterial activity of SR-3 was affected by the action of peptidase (Proteinase-K), but the absence of inhibition against Pseudomonas aeruginosa ATCC27853 was only observed at $10 \mathrm{mg} / \mathrm{mL}$ concentration of the

proteolytic enzyme. SR-3 stored at $-20{ }^{\circ} \mathrm{C}$, maintain its antibacterial activity for up to 180 days (Table 2.0).

Similar activities of temperature, enzymes and time of storage were also reported by Teixeira et. al. (2013). In contrast, Ebbensgaad et. al. (2015) reported the stability of their AMPs after exposure to temperature of up to $90^{\circ} \mathrm{C}$ for 30 minutes while a few of these peptides retained antimicrobial activity for up to 30 minutes of exposure to proteinase $\mathrm{K}$.

MIC determination

The inhibitory activities of the SR-2, SR-3 and SR4 fractions against the selected organisms including Gram-positive, Gram-negative bacteria and yeast were tested using 96-wells microplate. SR-3 was most effective against Salmonella typhii ATCC14028 having the lowest MIC of $0.05 \mathrm{mg} / \mathrm{mL}$, followed by Citrobacter freundii ATCC8090 with MIC of $0.10 \mathrm{mg} / \mathrm{mL}$. Escherichia coli ATCC 25922, Staphylococcus aureus ATCC 25913, Pseudomonas aeruginosa ATCC 27853 and Candida albicans ATCC3147 had MIC at 0.20 $\mathrm{mg} / \mathrm{mL}$ for both SR-2 and SR-3 (Table 3.0).

Table 2: Effect of selected physicochemical properties of SR-3 on zones of inhibition ( $\mathrm{mm}$ ) of Pseudomonas aeruginosa ATCC 27853

\begin{tabular}{lll}
\hline Parameter & & Diameter of zones of inhibition $(\mathbf{m m})$ \\
\hline Temperature & $50^{\circ} \mathrm{C}$ & $19.00 \pm 0.79$ \\
& $90^{\circ} \mathrm{C}$ & 0.0 \\
Proteinase K & $5 \mathrm{mg} / \mathrm{mL}$ & $12.00 \pm 0.31$ \\
& $10 \mathrm{mg} / \mathrm{mL}$ & 0.0 \\
Storage Time (days) & 90 & $21.00 \pm 1.09$ \\
& 180 & $20.50 \pm 1.37$ \\
\hline
\end{tabular}

Table 3: Minimum inhibitory concentration of purified AMPs from S. regularis against tested organisms

\begin{tabular}{llll}
\hline \multirow{2}{*}{ Test Organisms } & \multicolumn{3}{l}{ MIC $(\mathrm{mg} / \mathbf{m L})$} \\
\cline { 2 - 4 } & SR-2 & SR-3 & SR-4 \\
\hline Escherichia coli ATCC 25922 & 0.20 & 0.20 & 0.20 \\
Staphylococcus aureus ATCC 25913 & 0.20 & 0.20 & $>0.40$ \\
Pseudomonas aeruginosa ATCC 27853 & 0.20 & 0.20 & 0.20
\end{tabular}


Aliyu et al. / Nig. J. Biotech. Vol. 38 Num. 2 : 84-91 (December 2021)

$\begin{array}{llll}\text { Citrobacter freundii ATCC 8090 } & 0.10 & 0.10 & 0.20 \\ \text { Salmonella typhii ATCC } 14028 & 0.10 & 0.05 & 0.20 \\ \text { Candida albicans ATCC 3147 } & 0.20 & 0.20 & >0.40\end{array}$

Peptide sequence determination

The peptide mass fingerprint (PMF) of Mascot webserver was used for the determination of the amino acid sequence of the purified fractions: SR2, SR-3 and SR-4 using the spectral peaks of each fraction produced by MALDI TOF/TOF MS. Peptide sequences for each fraction were determined as IHAGKTVPIVK, MHLLWR and LTGQIKNGLSGR, respectively and their molecular weights of SR-2,
SR-3 and SR-4 were 1162.10 Da, 854.09 Da and 1242.61 Da respectively as analysed by MALDITOF/TOF MS (Fig. 2). The experimentally determined molecular weights correspond well with the calculated molecular weights (1162.44 $\mathrm{Da}$, 855.07 Da and 1243.62 Da) of SR-2, SR-3 and SR-4 respectively obtained with the ExPASy ProtParam tool (https://web.expasy.org/cgibin/protparam/protparam ).
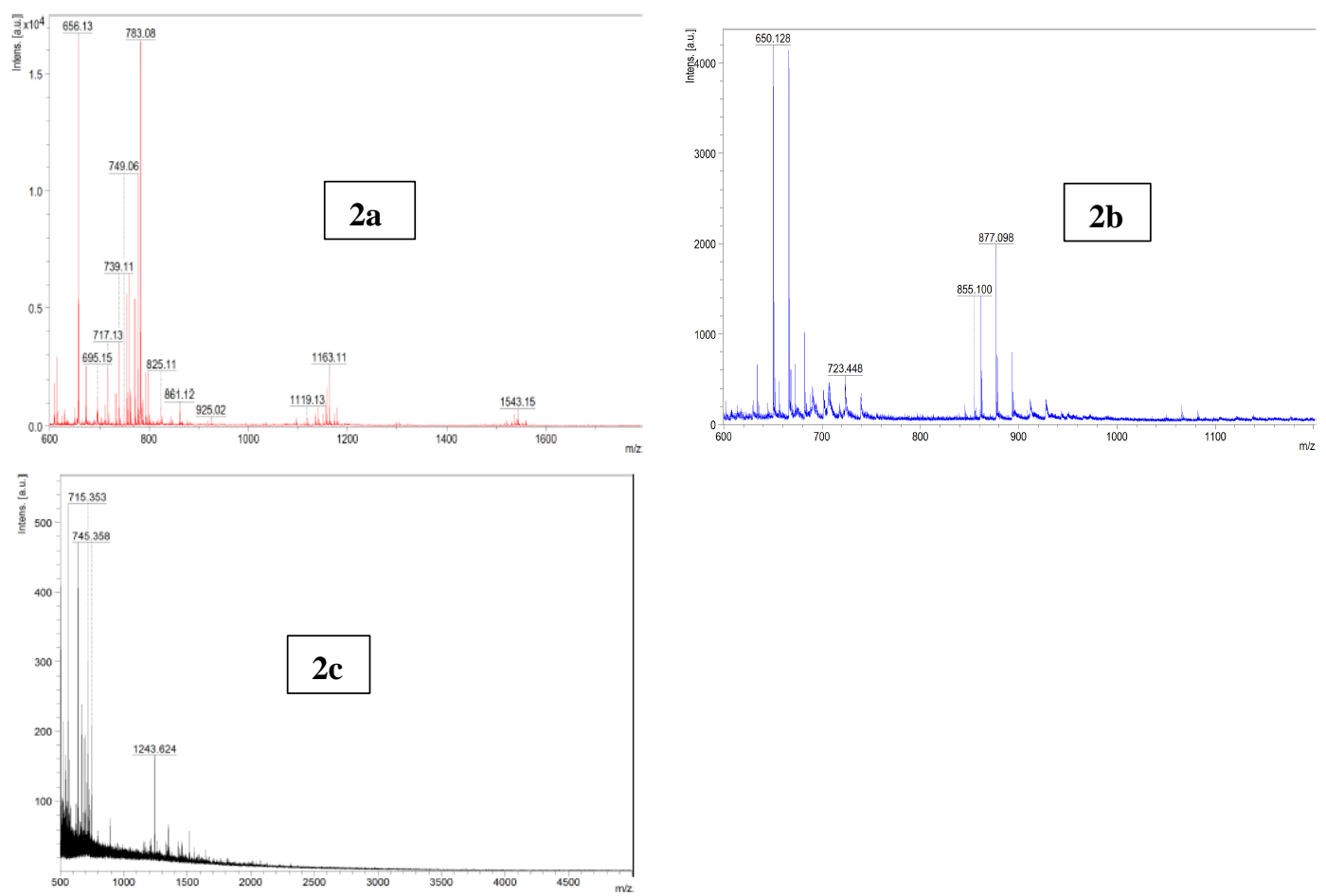

Figure 2: MALDI TOF/TOF MS spectral of purified fractions SR-2 (2a), SR-3 (2b) and SR-4 (2c) respectively

Also, the peptide net charges and isoelectric point $(p I)$ of the fractions (SR-2.SR-3 and SR-4) are +2 , $+1,+2$ and $10,9.52,11$ respectively. On the hydrophobic amino acid constituents which is important for antimicrobial activity, SR-3 had highest of $67 \%$ hydrophobicity, followed by SR-2 (46\%) and SR-4 contains only $25 \%$ hydrophobic amino acids which could be among the reasons why we observed the trend of their antimicrobial activity to be SR-3>SR-2>SR-4. These low molecular weights SR-2, SR-3 and SR-4 sequences were designated as Regularin-2, Regularin-3 and Regularin-4 respectively. As reported earlier by
Kim et. al., (2005) and Asoodeh et. al. (2012), the hallmarks of most AMPs are the possession of net positive charge (cationic) and high (>40 \%) hydrophobic amino acids residues. These low molecular weight AMPs are potential sources for developing new antimicrobial agents to improve traditional drug resistance (Wu et. al., 2021).

\section{Conclusion}

The authors report the isolation, purification and sequencing of broad spectrum AMPs from skin secretion of African common toad $S$. regularis. All the three regularins (Regularin-2, Regularin-3, 
Aliyu et al. / Nig. J. Biotech. Vol. 38 Num. 2 : 84-91 (December 2021)

and Regularin-4) are novel peptides. Regularin-3 had best antimicrobial activity than the other regularins and could be considered antimicrobial drug candidate. This is the first time antimicrobial property of the skin secretion of Sclerophrys regularis will be reported. In Africa, drug discovery from amphibians are largely untapped, and this study therefore provides a strong fact for the research focus of bioprospecting antimicrobials against multiple antibiotic resistant organisms.

\section{Ethical approval}

An application was made to and the approval granted by University of Ilorin Ethical Review

\section{References}

Adriano, B., Mario, L.T. and Andreia, D.R. (2013). Characterization of an antimicrobial peptide produced by Bacillus subtilis subsp. Spizezinii showing inhibitory activity towards Haemophilus parasuis, Microbiol.,159, 980-988.

Artika, M.I., Pinontoan, S. and Kusrini, M.D. (2015). Antibacterial Activity of Skin Secretion of Bleeding Toad Leptophrynecruentuta and Javan Tree Frog Rhacophorusmargaritifer, American J. of Biochem. and Biotech., 11(3): 127-131. DOI: 10.3844/ajbbsp.2015.127.131

Asoodeh, A., Zardinia, H.Z. and Chamanic, J. (2012). Identification and characterization of two novel antimicrobial peptides, temporin-Ra and temporin-Rb, from skin secretions of the marsh frog (Rana ridibunda), J. Pept. Sci.; 18: 10-16. DOI 10.1002/psc.1409

CDC (2020). Antibiotic and Antimicrobial Resistance. Retrieved on $1^{\text {st }}$ July, 2021 from https://www.cdc.gov/drugresistance/biggestthreats.html

Chen, C., Hou, J., Tanner, J.J. and Cheng, J. (2020). Bioinformatics Methods for Mass Spectrometry-Based Proteomics Data Analysis, Int. J. Mol. Sci. 21, 2873; doi:10.3390/ijms21082873

Chengbang, M., Linyuan, H., Dong, C., Lei, W., Chen, L., Xinping, X., Tianbao, C., Chris, S. and Mei, Z. (2017). Dermaseptin-PH: A Novel Peptide with Antimicrobial and Anticancer Activities from the Skin Secretion of the South American OrangeLegged Leaf Frog, Pithecopus (Phyllomedusa) hypochondrialis, Molecules, 22, 1805; doi:10.3390/molecules22101805.
Committee through the approval number UERC/ASN/2019/1603.

\section{Acknowledgements}

This work was supported by the Tertiary Education Trust Fund (TetFund) through University of Ilorin, Ilorin Nigeria. We also appreciate the support and assistance of Dr. Prathama S. Mainkar of Organic Synthesis and Process Chemistry, Indian Institute of Chemical Technology Hyderabad, India.

Conlon, J.M. and Sonnevend, A. (2011). Clinical applications of amphibian antimicrobial peptides. J. Med. SCi., 4: 62-72. DOI: 10.2174/199632700110402006

Creative proteomics, Protein Identification Peptide Mass Fingerprinting (2017). Retrieved July 30, 2021, from

https://www.youtube.com/watch?v=4xSUWK ue WI

Dailami, M., Artika, M.I. and Kusrini, M.D. (2016). Analysis and Prediction of Some Histone derived Antimicrobial Peptides from Toads Duttaphrynusmelanostictus and Phyrinoidisasper, J. of Pure and Applied Chem. Research, 5(2): 6776.

Ebbensgaard, A., Mordhorst, H., Overgaard, M.T., Nielsen, C.G., Aarestrup, F.M., Hansen, E.B. (2015). Comparative Evaluation of the Antimicrobial Activity of Different Antimicrobial Peptides against a Range of Pathogenic Bacteria. PLOS ONE 10(12):

doi:10.1371/journal.pone.0144611

Genomics Lab: Protein identification and characterization using MALDI-MS. (2012). Retrieved July 1, 2021, from https://www.youtube.com/watch?v=sAJ9FiuxUh A

Govender, T., Dawood, A., Esterhuyse, A. and Katerere, D.R. (2012). Antimicrobial properties of the skin secretions of frogs. S. Afr. J. Sci., 108: 1-6. DOI: $10.4102 /$ sajs. v108i5/6.795

James, M. A., Ye, Y., Lan, Y., Kozlowska, J., Lam, J.K.W. and Drake, A.F. (2010). Structural contributions to the intracellular targeting strategies of antimicrobial peptides Biochimicaet Biophysica Acta 1798: 1934-1943 
Aliyu et al. / Nig. J. Biotech. Vol. 38 Num. 2 : 84-91 (December 2021)

Katerere, D. R., Dawood, A., Esterhuyse, A. J., Vismer, H. F. and Govender, T. (2013). Antifungal activity of epithelial secretions from selected frog species of South Africa, African J. of Biotech., Vol. 12(45), pp. 6411-6418,

DOI: $10.5897 / A J B 2013.12036$

Kim, S., Kim, S.S. and Lee, B.J. (2005). Correlation between the activities of a-helical antimicrobial peptides and hydrophobicities represented as RP HPLC retention times, Peptides 26 (2005) 20502056

Libério, M., Bastos, I.M.D., Junior, O.R.P., Fontes, W. and Santana, J.M. (2014). The crude skin secretion of the pepper frog Leptodactylus labyrinthicus is rich in metallo and serine peptidases. PloS ONE, 9: e96893-e96893. DOI: 10. 1371/journal.pone.0096893.

Liu, Y., Shi, D., Wang, J., Chen, X., Zhou, M., Xi, $X$. ., Cheng, J., Ma, C., Chen, T., Shaw, C. and Wang, L. (2020) A Novel Amphibian Antimicrobial Peptide, Phylloseptin-PV1, Exhibits Effective AntiStaphylococcal Activity Without Inducing Either Hepatic or Renal Toxicity in Mice. Front. Microbiol. 11:565158. doi: 10.3389/fmicb.2020.565158

Mor, A.; Nicolas, P. (1994). Isolation and structure of novel defensive peptides from frog skin. Eur. J. Biochem, 219, 145-154.

Moussa, A.E., Olama, Z., Moussad, E.E., Kavunja, H. and El-Dakdouki, M.H. (2015). Characterization of Anuran Skin Peptides: An Alternative to the Classical Therapeutic Agents Used for MDR Pathogens, Int.J.Curr.Microbiol.App.Sci 4(10): 889-900

Siano, A., Gatti, P.I., Imaz, M.S., Zerbini, E. and Simonetta, A.C. (2014). A comparative study of the biological activity of skin and granular gland secretions of Leptodactyluslatrans and Hypsiboaspulchellus from Argentina, Rec. Nat. Prod., 8: 128-135.

Teixeira, M.L., Rosa, A.D. and Brandelli, A. (2013). Characterization of an antimicrobial peptide produced by Bacillus subtilis subsp. spizezinii showing inhibitory activity towards Haemophilus parasuis, Microbiology, 159, 980-988. DOI 10.1099/mic.0.062828-0
Wu, M., He, Y., Dinghani, D.Y.A., Wang, Y., Yaohui Hu, Y., Wang, H., Wang, B., Lv, B., Yu, H. and Wen, H. (2021). Purification and CDNA Cloning of Antimicrobial Peptides from the Skin Secretion of the Chinese Frog Rana chensinensis, International J. of Peptide Research and Therapeutics, 27:293-300 doi.org/10.1007/s10989-020-10074-y

Yergey, A.L., Coorssen, J.R., Backlund, P.S., Blank, J.P.S., Humphrey, G.A., Zimmerberg, J., Campbell, J.M. and Vestal, M.L. (2002). De novo Sequencing of Peptides Using MALDI/TOF-TOF, $J$. Am Soc. Mass Spectrum, 13, 784-791 